\title{
Economic Optimization of Binary Fluid Cycle Power Plants for Geothermal Systems
}

by

R. A. Walter and S. W. Wilson

September 1976

Prepared for the Energy Research and Development Administration under Contract $E(45-1)-1830$ 


\section{DISCLAIMER}

This report was prepared as an account of work sponsored by an agency of the United States Government. Neither the United States Government nor any agency Thereof, nor any of their employees, makes any warranty, express or implied, or assumes any legal liability or responsibility for the accuracy, completeness, or usefulness of any information, apparatus, product, or process disclosed, or represents that its use would not infringe privately owned rights. Reference herein to any specific commercial product, process, or service by trade name, trademark, manufacturer, or otherwise does not necessarily constitute or imply its endorsement, recommendation, or favoring by the United States Government or any agency thereof. The views and opinions of authors expressed herein do not necessarily state or reflect those of the United States Government or any agency thereof. 


\section{DISCLAIMER}

Portions of this document may be illegible in electronic image products. Images are produced from the best available original document. 
ECONOMIC OPTIMIZATION OF BINARY FLUID

CYCLE POWER PLANTS

FOR GEOTHERMAL SYSTEMS

By

R. A. Walter and S. W. Wilson

September 1976

Battelle

Pacific Northwest Laboratories

Richland, Washington 99352 


\section{CONTENTS}

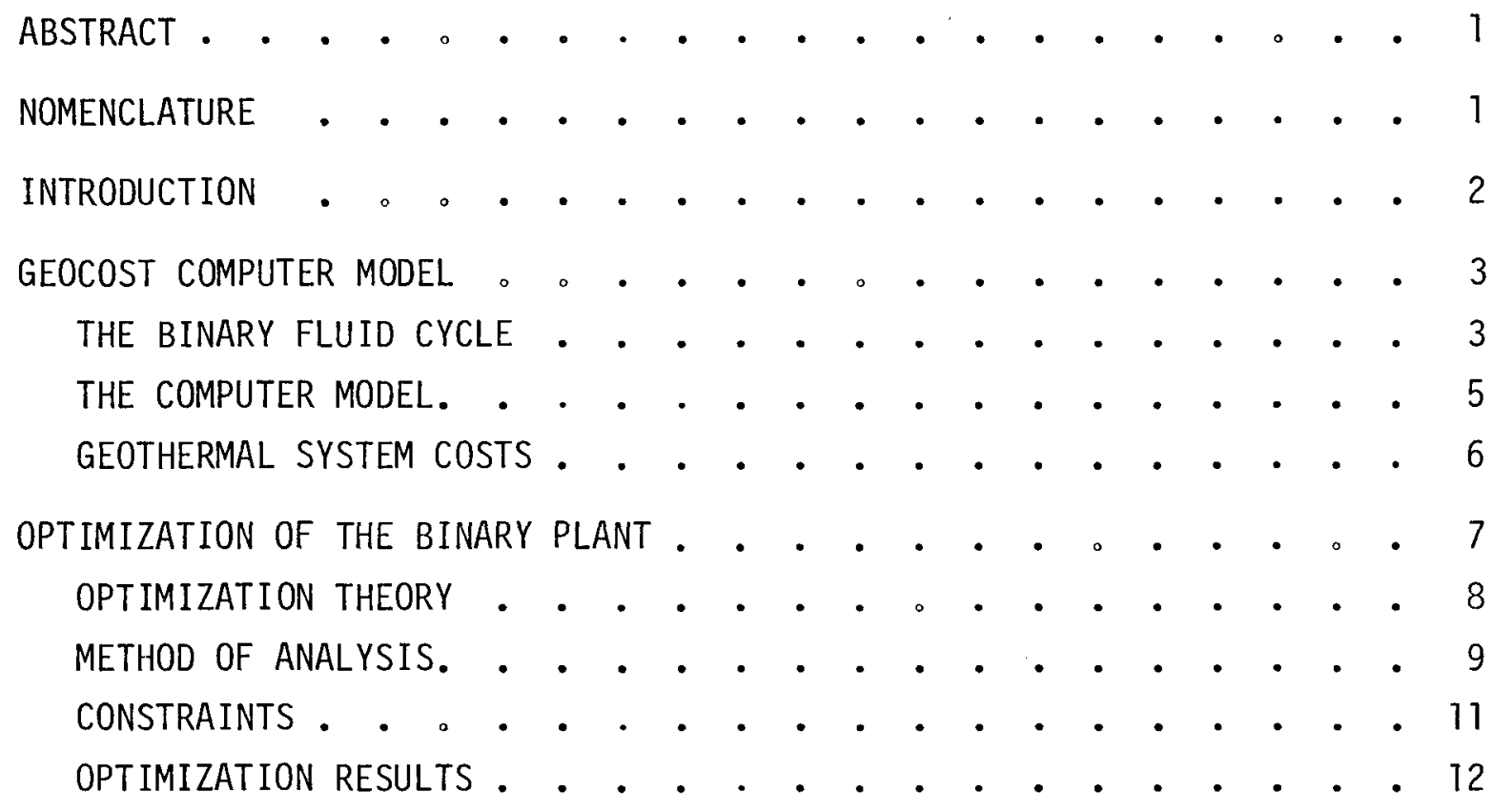

COMPARISON OF OPTIMIZATION RESULTS WITH COST OF POWER • • • • $\quad$ • 15

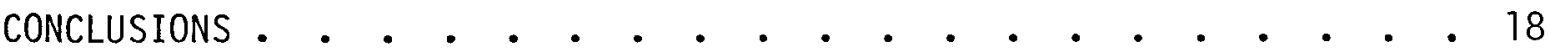

REFERENCES • • • • • • • • • • • • • • • • • • • • 20 


\section{LIST OF FIGURES}

1 Subcritical Binary Fluid Cycle Power Plant. . . . . . . . 4

2 Cash Flow Diagram for Geothermal Power Plant • • • . . . 6

3 Subcritical Cycle . . . . . . . . . . . . 10

4 Supercritical Cycle . . . . . . . . . . . 10

5 Optimization Constraints. . . . . . . . . . . 11

6 Geothermal Temperature $-250^{\circ} \mathrm{F}\left(394^{\circ} \mathrm{K}\right)$ and $200^{\circ} \mathrm{F}\left(366^{\circ} \mathrm{K}\right)$. . 12

7 Geothermal Temperature $-300^{\circ} \mathrm{F}\left(422^{\circ} \mathrm{K}\right)$. . . . . . . 12

8 Geothermal Temperature $-350^{\circ} \mathrm{F}\left(450^{\circ} \mathrm{K}\right) \cdot$. . . . . . 13

9 Geothermal Temperature $-400^{\circ} \mathrm{F}\left(477^{\circ} \mathrm{K}\right)$. . 。 . . . . . 13

10 Geothermal Temperature $-450^{\circ} \mathrm{F}\left(404^{\circ} \mathrm{K}\right)$. . . . . . . . 14

11 Geothermal Temperature $-500^{\circ} \mathrm{F}\left(533^{\circ} \mathrm{K}\right)$. . . . . . . 14

12 P-H Diagram for Isobutane - Location of Optimum States . • . 17

\section{LIST OF TABLES}

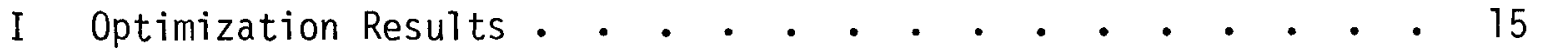


ECONOMIC OPTIMIZATION OF BINARY FLUID CYCLE POWER PLANTS

FOR GEOTHERMAL SYSTEMS

R. A. Walter and S. W. Wilson

\section{$\underline{A B S T R A C T}$}

An analytical model called GEOCOST has been constructed and used to study the design, performance and cost of geothermal power plants using the binary fluid cycle. The GEOCOST computer program simulates all the major components of a geothermal system and calculates the cost of energy production by equating the present worth of revenues and expenses including investment return over the economic life of the plant and/or reservoir. The characteristics of the binary fluid cycle power plant are determined for a variety of geothermal resources, working fluids, and cycle types. An optimization technique based upon the maximum use of available energy in the geothermal fluid is generated, and results of this optimization technique are compared with computed cost data for a variety of binary power plants.

\section{NOMENCLATURE}

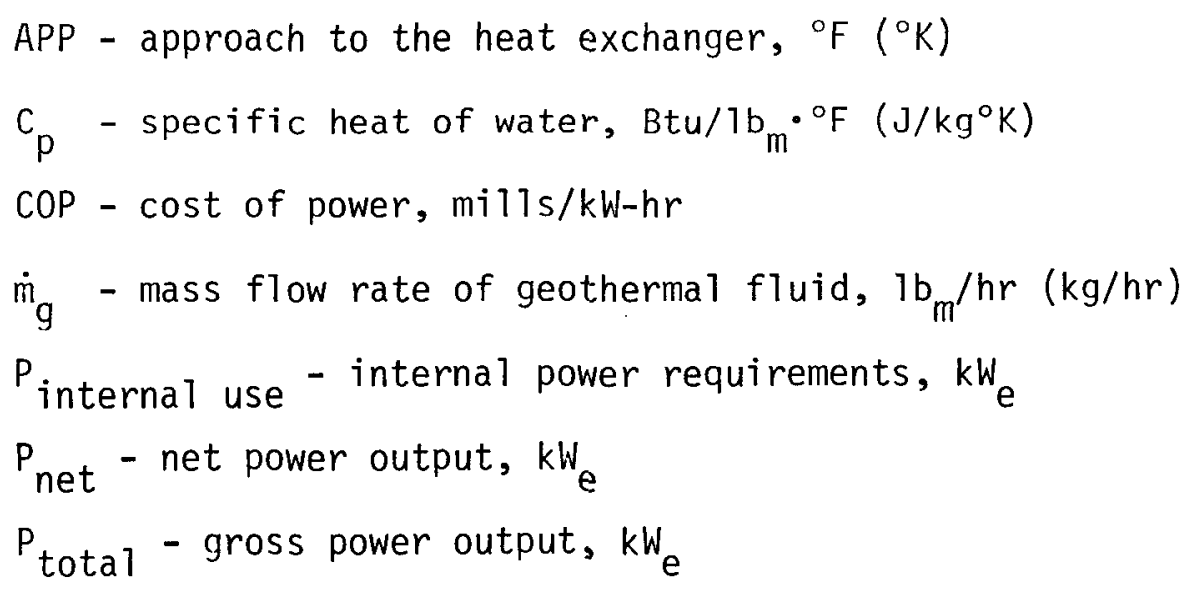




$$
\begin{aligned}
& T_{h} \text { - source temperature, }{ }^{\circ} \mathrm{R}\left({ }^{\circ} \mathrm{K}\right) \\
& \mathrm{T}_{0} \text { - sink temperature, }{ }^{\circ} \mathrm{R}\left({ }^{\circ} \mathrm{K}\right) \\
& W_{\max } \text { - maximum reversible work, } B t u / 1 b_{m}(\mathrm{~J} / \mathrm{kg}) \\
& \text { WTI - geothermal fluid inlet temperature, }{ }^{\circ} \mathrm{R}\left({ }^{\circ} \mathrm{K}\right) \\
& \Delta Q \quad \text { - net heat transfer } \\
& \Delta W \quad \text { - net work produced } \\
& n \text { - efficiency, } \% / 100 \\
& n_{u} \text { - utilization efficiency, } \% / 100
\end{aligned}
$$

\section{$\underline{\text { INTRODUCTION }}$}

Geothermal energy has been identified as a potentially large source for electrical power production in the United States and other countries. Efforts to utilize the vast geothermal reserves has resulted in the design of numerous power production facilities. The binary fluid cycle has been recommended as a power plant concept for those geothermal reservoirs which are relatively low in temperature or contain high percentages of dissolved solids and noncondensible gases. In order to assess the feasibility of this type of power plant for use with geothermal resources, a computer model of the entire geothermal power production facility has been developed. This computer program determines main plant component sizes, calculates the overall performance for a variety of power plant designs, and computes the cost of producing electricity for the binary fluid cycle power plant with a minimum cost deisgn.

This paper provides a description of the binary fluid cycle for use with geothermal resources, a general outline of the computer model, and a description of the costing method. Also contained in this paper is a detailed derivation of the plant optimization technique, with the results of an optimization study using isobutane as the working fluid. These results are compared with computed power plants costs to provide proof of the location of minimum cost designs for power plants operating over a range of geothermal resource conditions. 


\section{GEOCOST COMPUTER MODEL}

The GEOCOST computer program has been developed at BattelleNorthwest under funding by the U.S. Energy Research and Development Administration (Bloomster, et al., Feb。1975) to meet the need for rapid and systematic calculations of the costs of geothermal power. GEOCOST combines both technical and economic factors into one systematic framework. The program, which simulates the production of electricity from most types of geothermal resources, is composed of two parts: a reservoir model which simulates the design and costs associated with the exploration, development, and operation of a geothermal reservoir; and a power plant model which simulates the costs associated with the design, construction and operation of the power plant. The costs from the reservoir model become energy supply costs to the power plant; the combined models form the complete energy production system.

\section{THE BINARY FLUID CYCLE}

The binary fluid cycle power plant is displayed in Figure 1 and is described below. In the model, the geothermal fluid is extracted from wells distributed throughout the reservoir and transmitted through insulated pipelines to the binary power plant. Through the use of well feed pumps and/or makeup pumps, the geothermal fluid is constantly maintained at a pressure exceeding the saturation pressure to prevent flashing and reduce solids precipitation. At the power plant, the geothermal fluid is passed through a series of heat exchangers, where thermal energy is transferred to a working fluid. These heat exchangers differ in design depending upon whether a supercritical or a subcritical cycle is employed.

In the supercritical cycle, the working fluid receives thermal energy while at a pressure exceeding its critical pressure. The subcritical cycle involves passing through the vapor dome, i.e., at a pressure below the critical pressure. The geothermal fluid is reinjected into the reservoir after passing through the heat exchangers. 


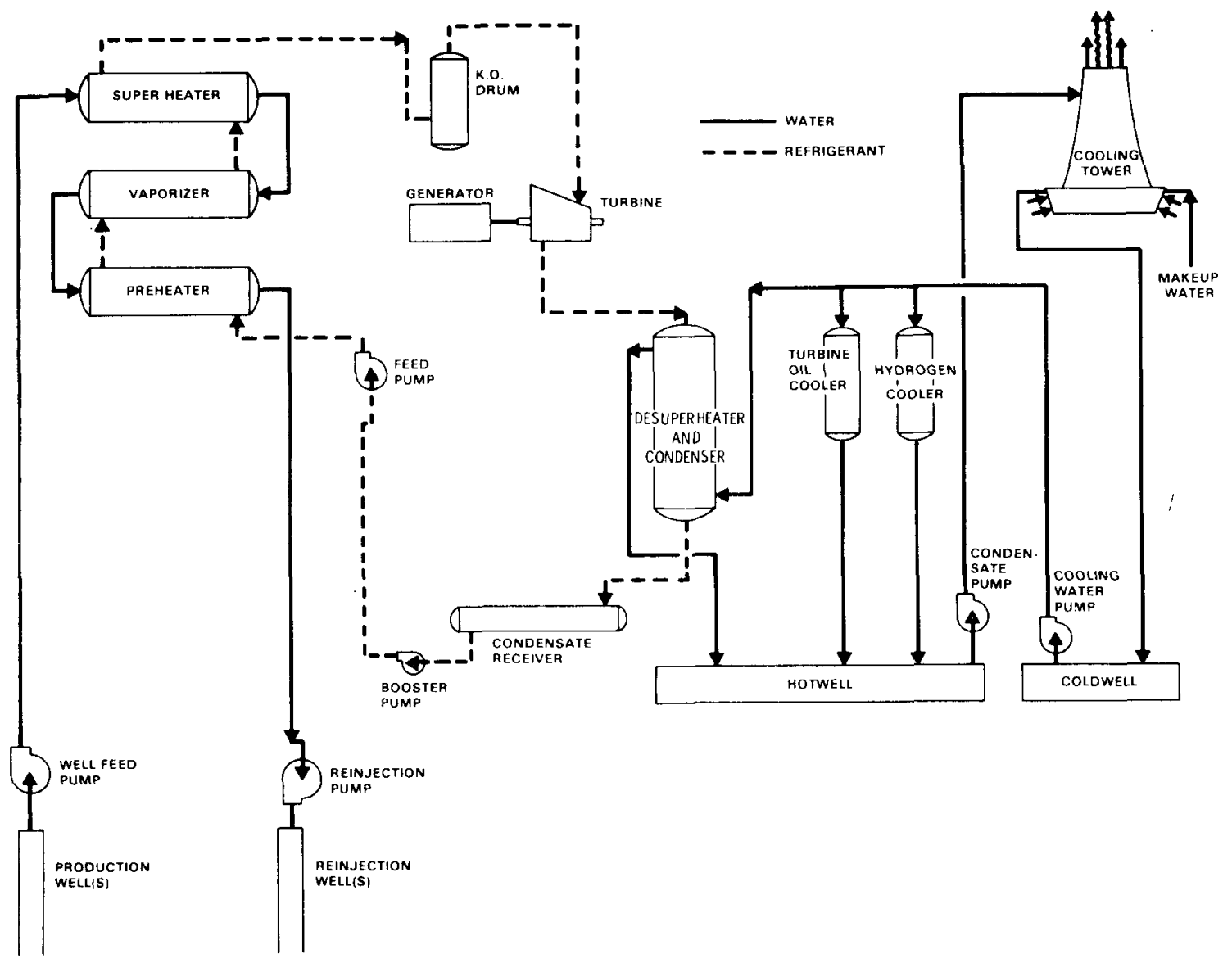

FIGURE 1. Subcritical Binary Fluid Cycle Power Plant

The working fluid is brought from a subcooled state to a superheated state and then expanded through a turbine which is coupled to a generator. The exhausted working fluid is condensed in a surface condenser supplied with cooling water. The condensed working fluid is collected in a condensate receiving tank and then repressurized with booster and feed pumps. The high pressure working fluid is then returned to the heat exchangers for repetition of the cycle.

Cooling water is supplied to the condenser, turbine oil cooler, and generator cooler from an induced-draft evaporative cooling tower. Makeup water to replace fluid lost due to evaporation, blow down, and drift is required for the cooling tower. Internal requirements for power include cooling tower fans, cooling water pumps, geothermal fluid feed pumps and feed pumps for the working fluid. 
The binary fluid cycle power plant is simulated using the following major components: geothermal fluid transmission piping and pumps, geothermal fluid/working fluid heat exchangers, working fluid turbine, generator, surface condenser, working fluid feed pumps, turbine oil cooler, generator cooler, cooling water pumps, evaporative cooling tower, and geothermal fluid reinjection piping. Component sizes, fluid flow rates, power output, and plant performance are determined. The properties of the geothermal fluid, working fluid, and cooling water are computed on a key state points throughout the power plant and transmission system. Both subcritical and supercritical cycles can be simulated. Nine different working fluids are available for use in the binary plant: isobutane, n-butane, Freon-11, Freon-12, Freon-21, Freon-22, Freon-113, Freon-114, and ammonia.

\section{THE COMPUTER MODEL}

A flow diagram for the GEOCOST computer model is shown in Figure 2. Wellhead conditions of the geothermal fluid, power plant type and size, cost of the wells and annual power production are the principle input requirements. The two main components of the program, the reservoir and power plant models, are linked through the fluid transmission and power plant subsystem models. Major outputs of GEOCOST include the transmission pipeline diameters and lengths, pipe schedule, number and description of production wells, well field layout, pumping requirements, insulation requirements, and costs for the reservoir. Power plant output includes the state point properties of all fluids present, the size and description of major plant components, mass flow rate requirements, internal power usage, overall performance information, and energy costs for an optimized plant design. 


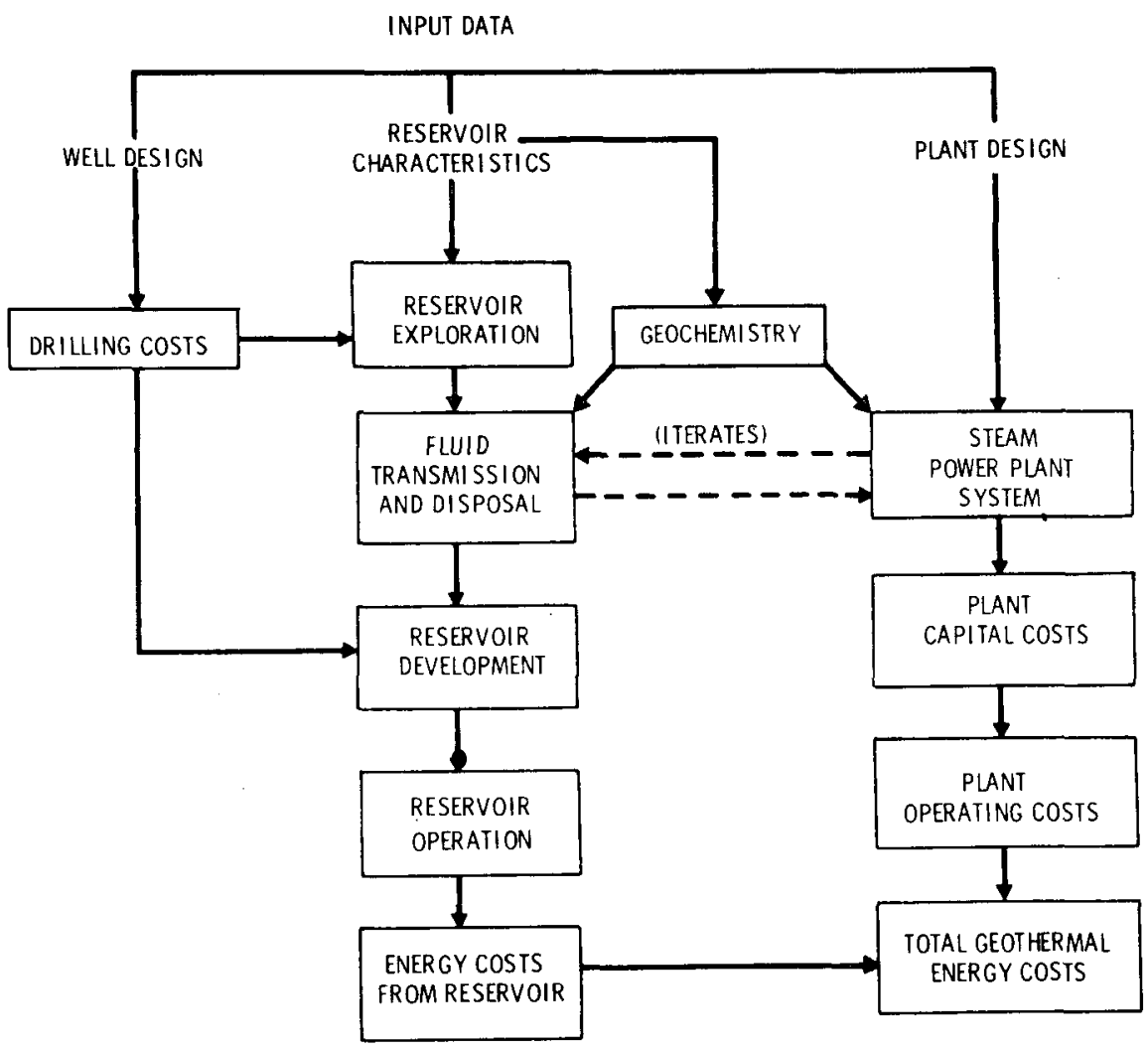

FIGURE 2. Cash Flow Diagram for Geothermal Power Plant

\section{GEOTHERMAL SYSTEM COSTS}

The computer model determines costs for both the reservoir and power plant submodels. Reservoir costs include capital and operating costs for exploration, development, and operation from the start of exploration through the life of the power plant. Exploration costs are based upon limited geothermal exploration data. Piping, insulation, and component costs are based on 1974 construction cost data. Annual operating expenses for the reservoir are calculated for the life of the power plant and include royalty payments, replacement well drilling, taxes, overhead and management, well and piping maintenance, and well redrilling costs. Based upon cash flow and energy supplied, the unit cost of energy is computed which will equate the present worth of the revenues and expenses for the reservoir. 
In the power plant submodel, the revenue to the reservoir is the energy supply expense to the power plant. Other power plant costs include the capital costs for each major plant component which were based upon data provided by industry vendors, utilities, proposed plant cost estimates, and published reports. The power plant model also provides for operating and maintenance costs, interim capital replacements, property insurance, revenue taxes, property taxes, and state and federal income taxes. The overall cost of generating electricity is calculated by equating the present worth of al1 revenues and expenses.

With a brief description of the binary fluid cycle, the logic of the computer model, and the method of costing, the process of actually selecting and designing a minimum cost power plant for different geothermal resources can be described. A technique of optimization which selects a minimum cost design is discussed in the following section and is followed by a comparison of the results of the optimization study with computed cost data.

\section{OPTIMIZATION OF THE BINARY PLANT}

Optimal utilization of the energy contained in geothermal reservoirs is necessary because of the relatively low energy-content of the geothermal fluid and the subsequent reduced efficiencies of power conversion schemes compared with those of conventional power plants. Developments in recent years have suggested that the use of a binary fluid cycle would be more economical for power production from low-temperature heat sources. Even though this conversion scheme may be superior, an effort must be made to utilize the geothermal resource as efficiently as possible. With the incentive of efficient energy utilization and the availability of a binary fluid cycle power plant model, a technique of optimization has been developed. This optimization technique is used to develop a binary cycle design which maximizes geothermal energy utilization based upon the limits of geothermal resource temperature and the prevailing ambient temperature for heat rejection. The development and use of this optimization technique are described in the following section. 


\section{OPTIMIZATION THEORY}

In an effort to design the binary power plant with a minimum cost, it was assumed that this design would also produce the maximum work from the available energy. Once the results of optimization were obtained, these results were to be compared with computed cost results to verify this assumption.

The maximum work that can be produced from any heat source is specified by the second law of thermodynamics. The second law states that the efficiency by which work $\Delta W$ can be produced by transferring heat $\Delta Q$ from a high temperature source at $T_{h}$ in a Carnot heat engine and rejecting heat to a low temperature sink at $T_{0}$ is as follows:

$$
\eta=\frac{\Delta W}{\Delta Q}=\frac{T_{h}-T_{0}}{T_{h}}
$$

More specifically, the maximum work available can be expressed in an integral form as a summation of heat transferred to an infinite number of smal1 Carnot heat engines between the source temperature $T_{h}$ and the sink temperature $\mathrm{T}_{0}$ 。 The net maximum work for a geothermal liquid source at temperatures varying between $T_{h, \text { in }}$ and $T_{h, \text { out }}$ can be expressed as:

$$
W_{\max }=-\int_{T_{h, \text { in }}}^{T_{h, \text { out }}}\left(\frac{T_{h}-T_{0}}{T_{h}}\right) d Q
$$
to read

With the assumption that $d Q=C_{p} d T_{h}$, the expression can be integrated

$$
W_{\max }=C_{p}\left[T_{h, \text { in }}-T_{h, \text { out }}-T_{0} \ln \frac{T_{h, \text { in }}}{T_{h, \text { out }}}\right]
$$


This quantity represents the maximum reversible work that can be produced and is commonty referred to as the change in availability, $\Delta B_{0} W_{\max }$ has units of $\mathrm{Btu} / 1 \mathrm{~b}_{\mathrm{m}}(\mathrm{J} / \mathrm{kg})$ with all temperatures in absolute units. The maximum total work that can be produced with a geothermal resource is $\dot{m}_{g} \times W_{\max }$. The actual work produced by the conversion process is the gross turbine output minus the internal power consumption, or $P_{\text {net }}{ }$ By dividing $P_{\text {net }}$ by $\left(\dot{m}_{g}\right.$ or $\left.W_{\max }\right)$, an expression for the efficiency of the geothermal system can be found and is identified as the utilization efficiency. By substituting in actual temperature limits, the expression for utilization efficiency becomes:

$$
\begin{aligned}
\eta_{u} & =\frac{P_{\text {net }} \times 3414}{\dot{m}_{g} \times W_{\max }} \\
& =\frac{\left(P_{\text {total }}-P_{\text {internal }} \text { use }\right) \times 3414}{\dot{m}_{g} \times C_{p} \times\left[W T 1-T_{0}-T_{0} \ln \left(W T 1 / T_{0}\right)\right]}
\end{aligned}
$$

The utilization efficiency is basically a quantity which reflects how effectively the available energy in the geothermal fluid is used in the power plant.

\section{METHOD OF ANALYSIS}

The utilization efficiency can be employed to establish an optimum cycle by locating the particular values of turbine inlet pressure and temperature of the working fluid which result in the highest value of $\eta_{u}$. This optimum point is based upon the entering geothermal fluid temperature, the prevailing sink temperature, and the selected working fluid. Figures 3 and 4 denote the Rankine cycles in question for this analysis, with the subcritical cycle shown in Figure 3 and the supercritical cycle in Figure 4. The states 2SATV and 2SATL are established by the prevailing sink condition and the temperature difference in the condenser. State 3 is set by the amount of pump work required to bring the working fluid up 
to its maximum pressure. Once the conditions are set at state 1 (turbine inlet) the entire cycle is established for both the subcritical and supercritical cycles, if the turbine efficiency is known.
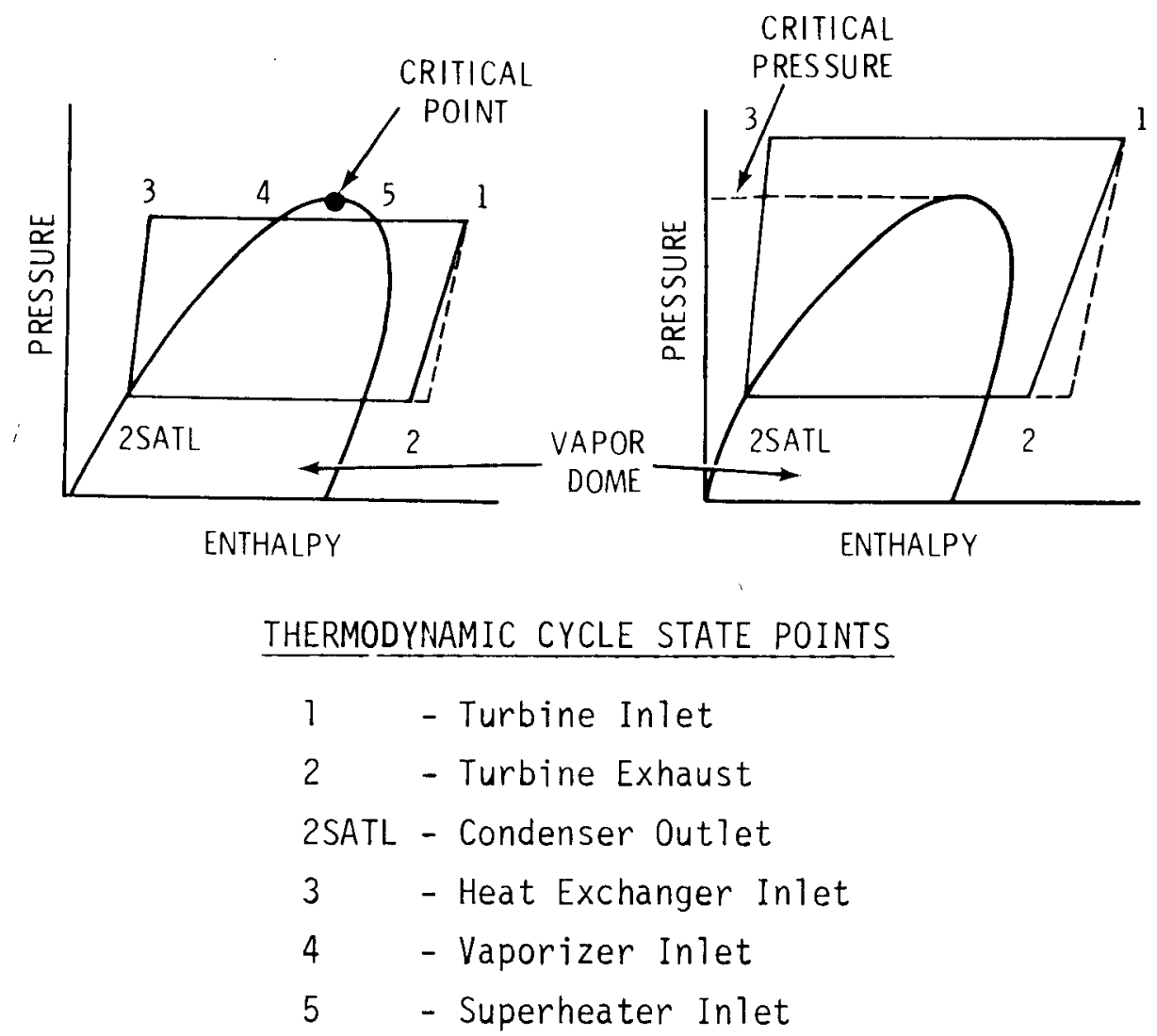

FIGURE 3. Subcritical Cycle FIGURE 4. Supercritical Cycle

The optimum turbine inlet state point was located for a particular geothermal fluid temperature and sink condition by examining a matrix of different turbine inlet pressures and approach values (approach $=$ geothermal fluid temperature - turbine inlet temperature) and by selecting the combination that resulted in the highest utilization efficiency. This technique was used to examine seven different geothermal fluid temperatures; $200,250,300,350,400,450$, and $500^{\circ} \mathrm{F}(366,394,422$, $450,477,505$ and $533^{\circ} \mathrm{K}$ ), using isobutane as the working fluid. 


\section{CONSTRAINTS}

To insure a reasonable cycle selection, a number of constraints were placed upon the optimization search. These constraints can be listed as follows:

a. minimum approach $=20^{\circ} \mathrm{F}\left(266^{\circ} \mathrm{K}\right)$

b. minimum heat exchanger pinch point $-15^{\circ} \mathrm{F}\left(264^{\circ} \mathrm{K}\right)$

c. minimum working fluid temperature (at state 2SATL) established at the sink temperature + range of the condenser $+5^{\circ}\left(258^{\circ} \mathrm{K}\right)$; this also establishing the turbine exhaust pressure

d. no expansion of the working fluid into the two-phase region was allowed in the turbine

e. maximum working fluid pressure $=1500$ psia $\left(1.0342 \mathrm{E} 7 \mathrm{~N} / \mathrm{m}^{2}\right)$

$f$. temperature of the geothermal fluid leaving the heat exchangers must be equal to or greater than the working fluid temperature at state $3+20^{\circ} \mathrm{F}\left(266^{\circ} \mathrm{K}\right)$.

These constraints were established on the basis of thermodynamic limitations and practical design considerations. Constraints (a), (c), (d) and (e) can be graphically displayed on a diagram of pressure versus enthalpy, as shown in Figure 5. The shaded area represents the general

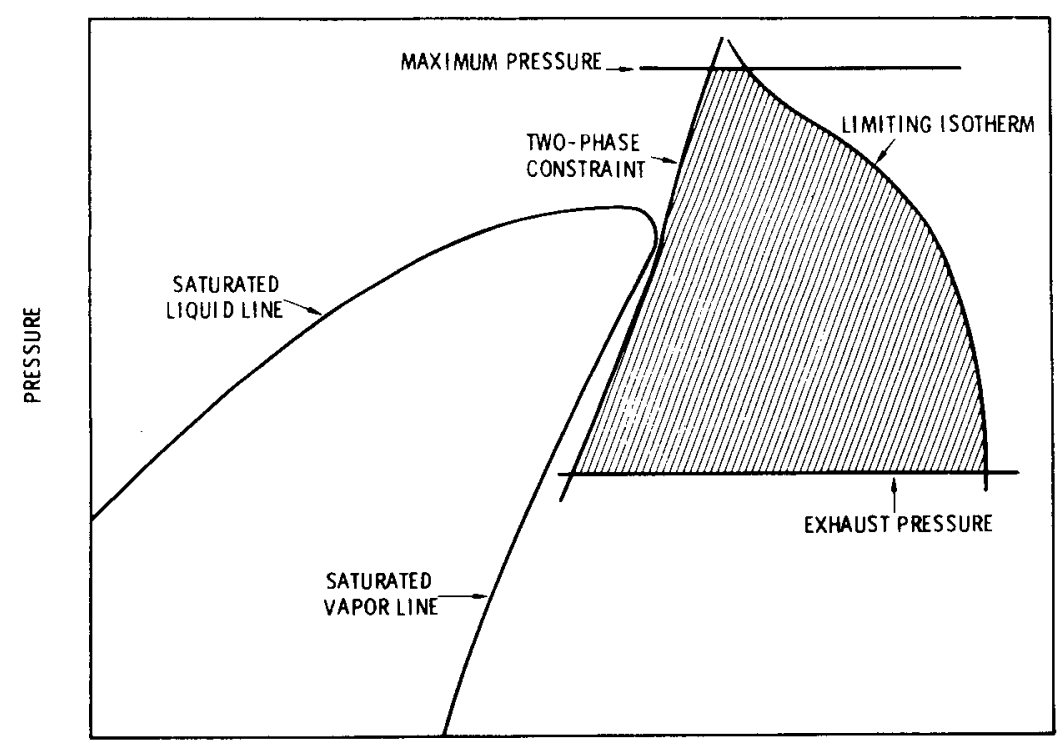

ENTHALPY 
search region mentioned in the previous paragraph. The optimum turbine inlet state will be found within this shaded area, subject to the additional constraints of (b) and (f).

\section{OPTIMIZATION RESULTS}

The results of the optimization search performed for the seven different geothermal fluid temperatures within the stated constraints can be displayed on a plot of utilization efficiency versus turbine inlet pressure, with the parametric variables of approach and geothermal fluid temperature. The results of these seven representative cases can be seen in Figures 6-11. In Figures 6 and 7, the approach 1 ines were terminated

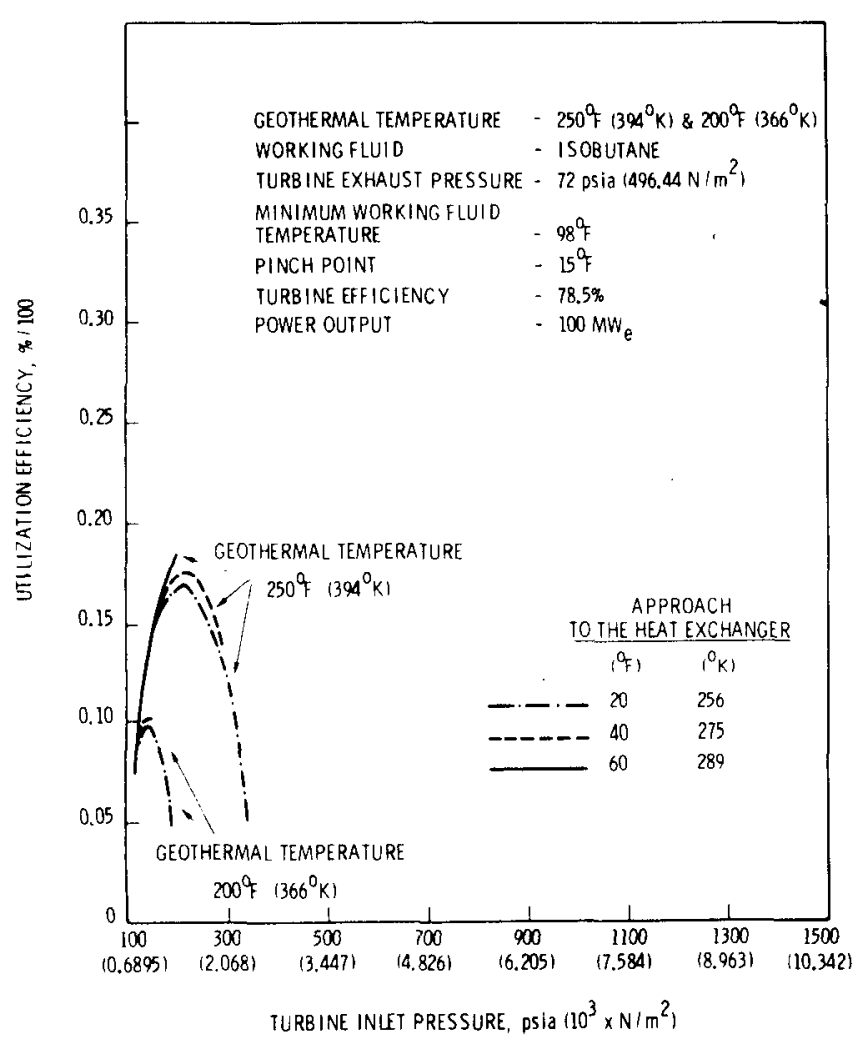

FIGURE 6. Geothermal Temperature $250^{\circ} \mathrm{F}\left(394^{\circ} \mathrm{K}\right)$ and $200^{\circ} \mathrm{F}\left(366^{\circ} \mathrm{K}\right)$

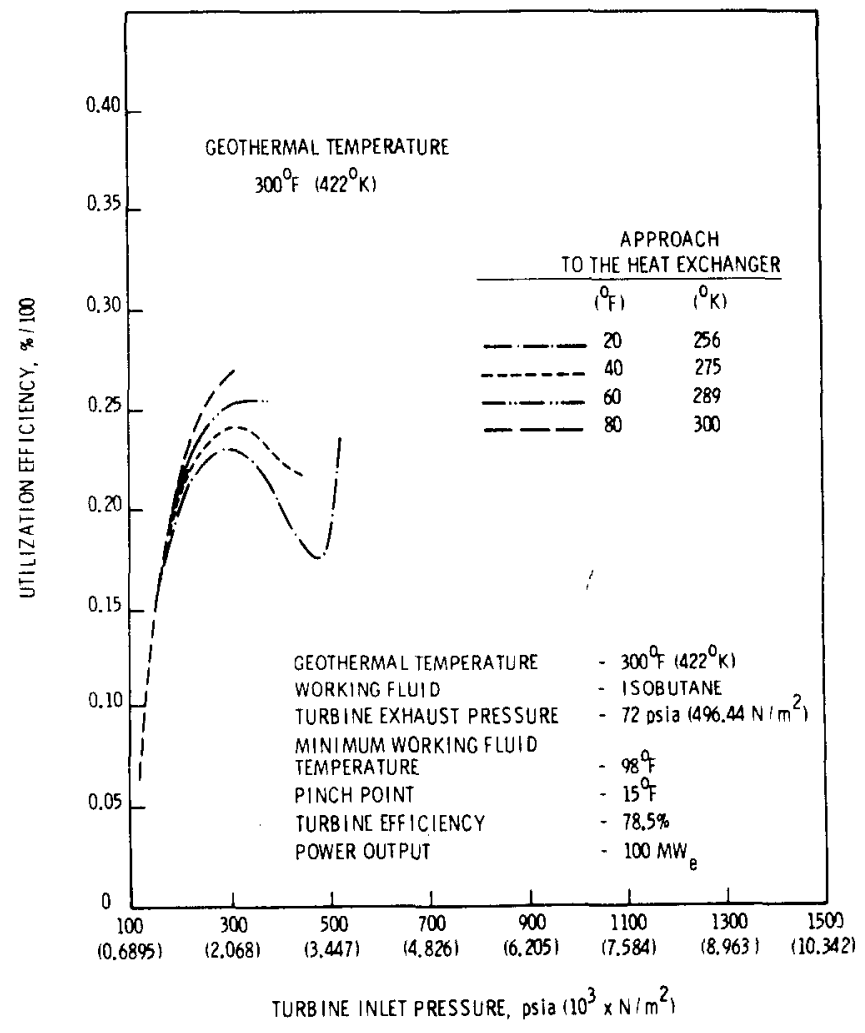

FIGURE 7. Geothermal Temperature $300^{\circ} \mathrm{F}\left(422^{\circ} \mathrm{K}\right)$ 
when two-phase exhaust began to appear upon turbine expansion - constraint (d). In Figure 8, all the approach lines were terminated for the same reason except the $60^{\circ} \mathrm{F}\left(289^{\circ} \mathrm{K}\right)$ approach 7 ine which terminated when the temperature of the geothermal fluid leaving the heat exchanger came within $70^{\circ} \mathrm{F}\left(266^{\circ} \mathrm{K}\right)$ of the working fluid temperature at state 3 - constraint ( $f$ ). With the higher geothermal temperature cases (Figures 9-11), the approach lines were terminated because of this constraint $(f)$ or because the maximum pressure was encountered - constraint (e).

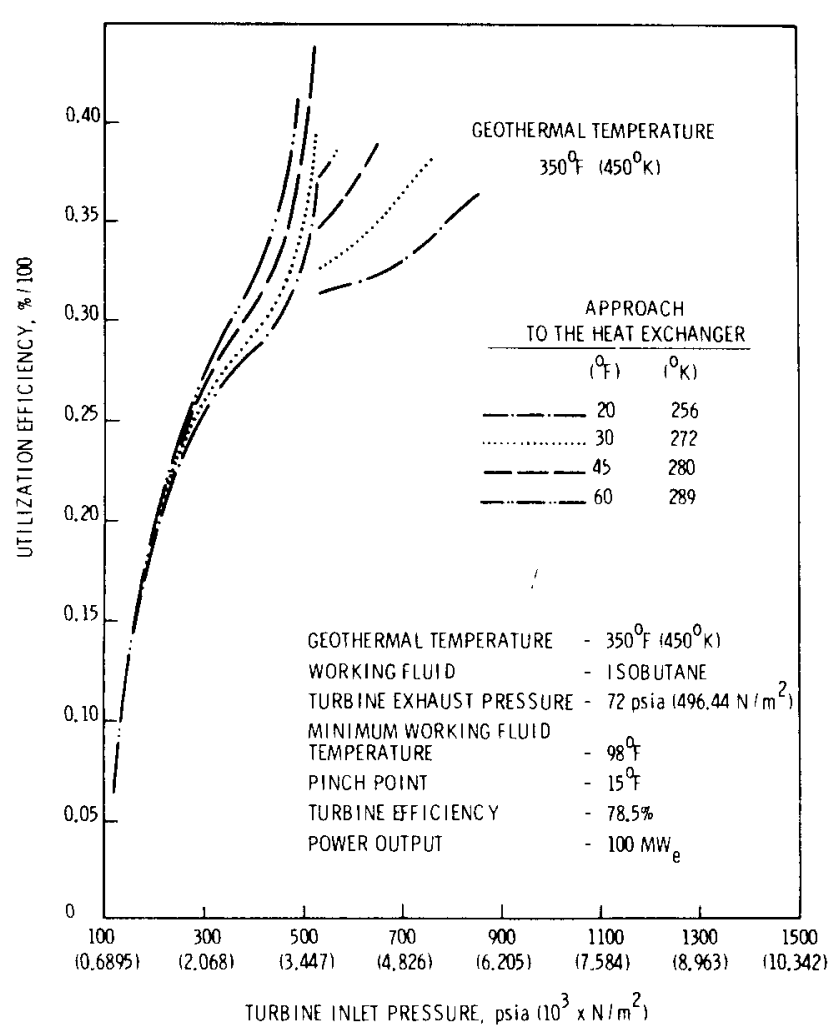

FIGURE 8. Geothermal Temperature $350^{\circ} \mathrm{F}\left(450^{\circ} \mathrm{K}\right)$



FIGURE 9. Geothermal Temperature $400^{\circ} \mathrm{F}\left(477^{\circ} \mathrm{K}\right)$ 


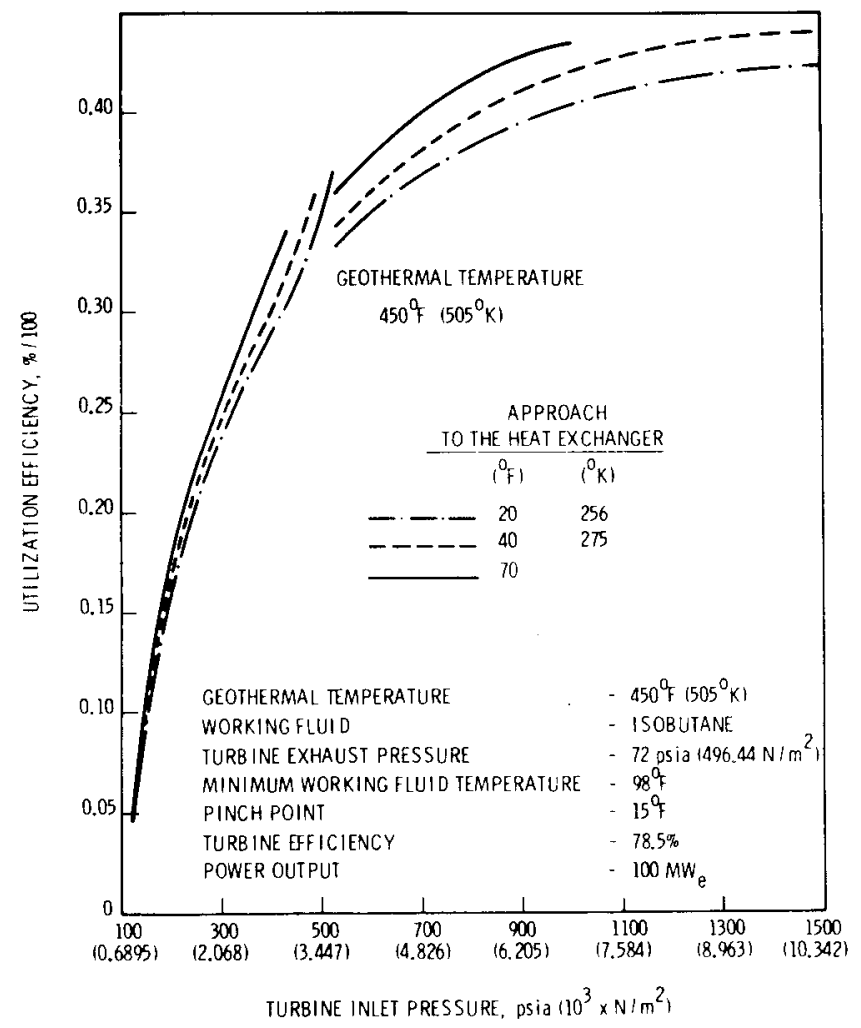

FIGURE 10. Geothermal Temperature $450^{\circ} \mathrm{F}\left(505^{\circ} \mathrm{K}\right)$

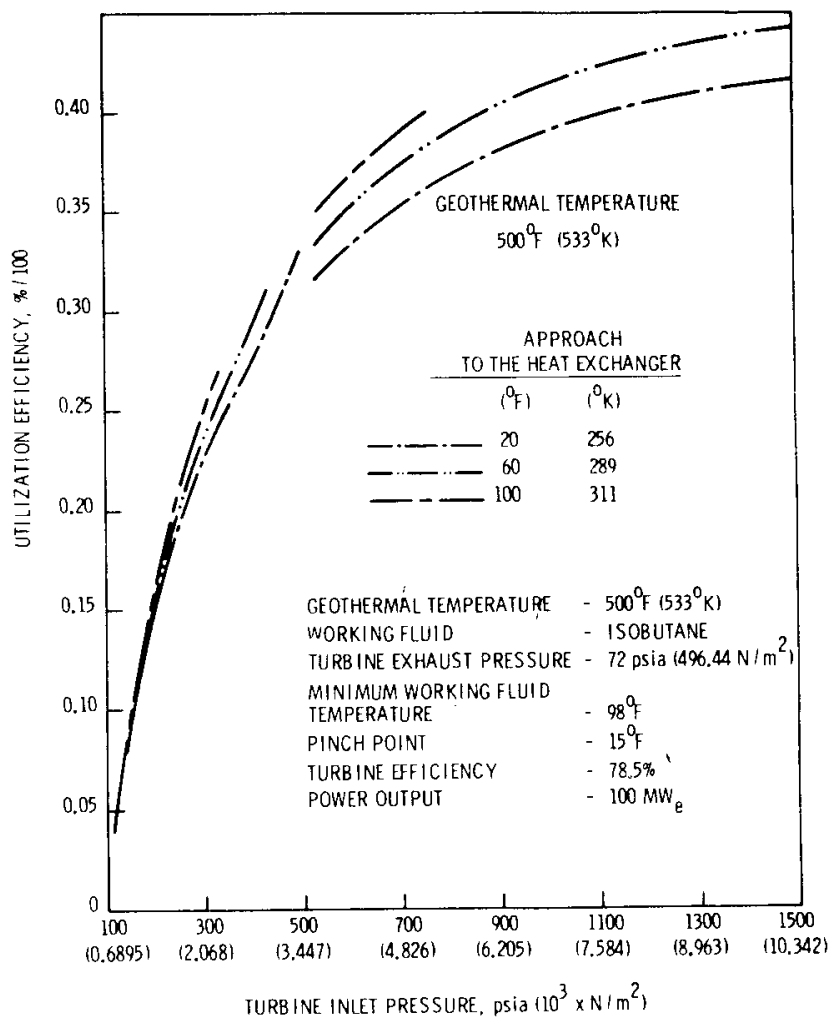

FIGURE 11. Geotherma1 Temperature $500^{\circ} \mathrm{F}\left(533^{\circ} \mathrm{K}\right)$

The $350^{\circ} \mathrm{F}\left(450^{\circ} \mathrm{K}\right)$ geothermal temperature case (Figure 8 ) illustrates a situation worth noting. At this temperature and conditions, a subcritical cycle seems more beneficial (from an efficiency point of view) but there is instability (i.e. small changes in pressure result in large changes in efficiency) in the subcritical cycle near the critical pressures $[529$ psia $\left(3.047 \mathrm{E} 6 \mathrm{~N} / \mathrm{m}^{2}\right)$ for isobutane]. So it is recommended that a supercritical cycle be chosen. This discontinuity in the "approach lines" at the critical pressure is caused by the nonlinearlity of fluid properties near the critical point. 
The results of the optimization study using the utilization efficiency are based upon thermodynamic reasoning, and a comparison of these results with computed costs is necessary to establish the validity of this analysis. The GEOCOST computer program provides an output value of the cost of power, COP, in mills $/ \mathrm{kW}-\mathrm{hr}$ for each of the cases considered in the optimization study. This economic yardstick was used to compare the minimum cost design with the design that has a maximum utilization efficiency.

For each particular geothermal fluid temperature considered, a matrix of cases was selected within the boundaries established in Figure 5 . The cost of power was computed by GEOCOST for each case considered in the constrained matrix, and the design that resulted in the minimum cost of power was saved for comparison with the maximum utilization efficiency design selection.

The results of the generation of cost data and the comparision with the optimization study can be shown in Table I. The following information is provided:

TABLE I. Optimization Results

\begin{tabular}{|c|c|c|c|c|c|c|}
\hline \multirow{2}{*}{$\begin{array}{l}\text { Geothermal } \\
\text { Fluid } \\
\text { Temperature } \\
\text { in }{ }^{\circ} \mathrm{F}\left({ }^{\circ} \mathrm{K}\right)\end{array}$} & \multirow{2}{*}{$\begin{array}{c}\text { Maximum } \\
\text { utilization } \\
\text { Efficiency } \\
(\% / 100) \\
\end{array}$} & \multicolumn{2}{|c|}{$\begin{array}{l}\text { Turbine Inlet Conditions at } \\
\text { Max. } \eta_{u}\end{array}$} & \multirow{2}{*}{$\begin{array}{l}\text { Energy Cost } \\
\text { at Max. }{ }^{n} u \\
\text { (mills } / \mathrm{kW}-\mathrm{hr} \text { ) }\end{array}$} & \multirow{2}{*}{$\begin{array}{c}\text { Minimum } \\
\text { Energy Cost } \\
\text { (mills/kw-hr) } \\
\end{array}$} & \multirow{2}{*}{$\begin{array}{c}\text { Cost } \\
\text { Deviation } \\
(\%) \\
\end{array}$} \\
\hline & & $\begin{array}{l}\text { Pressure } \\
\text { in psia }\left(\mathrm{N} / \mathrm{m}^{2}\right)\end{array}$ & $\begin{array}{l}\text { Temperature } \\
\text { in }{ }^{\circ} \mathrm{F}\left({ }^{\circ} \mathrm{K}\right) \\
\end{array}$ & & & \\
\hline $200(366)$ & 0.100 & $140(9.653 E 5)$ & $159(343.7)$ & 248.1 & 239.0 & 3.8 \\
\hline $250(394)$ & 0.183 & $200(1.379 \mathrm{E} 6)$ & $185(358.2)$ & 87.24 & 86.28 & 1.1 \\
\hline $300(422)$ & 0.269 & $310(2.137 \mathrm{E} 6)$ & $220(377.6)$ & 43.99 & 43.99 & 0.0 \\
\hline $350(450)$ & 0.390 & 651 (4.488E6) & $305(424.8)$ & 28.50 & 27.22 & 4.7 \\
\hline $400(477)$ & 0.425 & $1341 \quad(9.246 \mathrm{E} 6)$ & $365(458.2)$ & 24.35 & 23.51 & 3.6 \\
\hline $450(505)$ & 0.440 & $1500 \cdot(1.034 \mathrm{E} 7)$ & $410(483.2)$ & 20.77 & 20.77 & 0.0 \\
\hline $500(533)$ & 0.440 & $1500(1.034 \mathrm{E} 7)$ & $440(499.8)$ & 18.26 & 18.18 & 0.4 \\
\hline
\end{tabular}


a. the optimum turbine inlet conditions for each geothermal fluid temperature considered

b. the computed utilization efficiency for each optimum selection

c. the cost of power for the optimum design based on (a)

d. the cost of power for the design which resulted in the lowest cost, irregardless of the optimum selection in (a)

e. the percentage difference between the two values of COP from (c) and (d).

The table indicates the close correlation between the cost of the optimum cycle selected by the utilization efficiency and the cost of the most economic design. Due to the limited resolution of case runs, some minimum cost designs are identical to the corresponding maximum $\eta_{u}$ designs. These results can also be shown on a pressure versus enthalpy diagram for isobutane in Figure 12. Notice in this figure the close correlation between optimum turbine inlet state points. The optimum selections based on maximum $\eta_{u}$ and minimum COP are shown for each geothermal fluid temperature considered.

Based on the performed analysis and comparison, a number of general statements concerning the optimum cycle selection can be made:

a. There exists a close correlation between the maximum utilization efficiency and the minimum cost of power. An optimum cycle can now be selected in GEOCOST without the need for large amounts of computer time to search a variety of designs; only the geothermal fluid temperature, sink temperature and type of working fluid are required to make the selection.

b. The utilization efficiency increases and the cost of power decreases for an optimum cycle, with increasing geothermal fluid temperature.

c. The selected working fluid turbine inlet temperature and pressure increase with increasing geothermal fluid temperature. 




FIGURE 12. P-H Diagram for Isobutane - Location of Optimum States 
d. With the given input conditions, there exists a geothermal fluid temperature below which a subcritical cycle is always recommended and above which a supercritical cycle is best.

e. The maximization of utilization efficiency results in the conclusion that the working fluid at turbine inlet should contain a minimum amount of superheat. Even though a highly superheated working fluid results in a more efficient extraction of energy in the turbine, this increase in conversion does not compensate for the increased geothermal fluid flow rate required to raise the working fluid to that high energy state. This conclusion is evident upon examination of Figure 12, where all selected optimum points lie near the saturated vapor 1 ine:

f. A low pinch point temperature difference in the heat exchangers is desirable; however, below a value of about $15^{\circ} \mathrm{F}\left(264^{\circ} \mathrm{K}\right)$ the size of the heat exchangers required increases rapidly due to the low thermal driving force.

g. The prevailing sink temperature is fixed for a particular design. The minimum working fluid temperature in the power plant should be as close to this temperature as possible without increasing the condenser surface area dramatically.

\section{CONCLUSIONS}

A comprehensive computer model of a binary fluid cycle power plant for use with geothermal resources has been developed. This computer model can be used to assess the technical and economic feasibility of the geothermal resource and to aid in the design of binary power plants. GEOCOST provides information on reservoir and transmission design, major plant components, fluid properties throughout the system, type of cycle employed, excepted net power output, cost of producing power, and plant performance and design. In addition, an optimization technique has been developed to rapidly select the power plant design with the highest utilization efficiency based upon the maximum use of available energy in the geothermal fluid. This 
optimization technique has shown a close correlation with the minimum cost of power and can be used to easily select a minimum cost geothermal plant design knowing the geothermal fluid temperature, the prevailing ambient temperature for heat rejection, and the selected working fluid. 


\section{REFERENCES}

Bloomster, C. H., et al., GEOCOST - A Computer Program for Geothermal Cost Analys is, BNWL-1888, Batte17e-Northwest Laboratories, Rich7and, WA., February 1975.

Bloomster, C. H., Economic Analys is of Geothermal Energy Costs, BNWL-SA-5596, Battel le-Northwest Laboratories, Richland, WA。, November 1975.

Milora, S. L. and Tester, J. W., Geothermal Energy as a Source of Electric Power, - Thermodynamic and Economic Design Criteria, MIT Press, Cambridge, Mass, 1976.

Walter, R. Ao, et al., Thermodynamic Modeling of Geothermal Power Plants, BNWL-1911, Battelle-Northwest Laboratories, Richland, WA., May 1975. 